Cite as: "Bodas Freitas, I.M.; Marques, R. A. and Silva, E. M. P. (2013). Emergent and Mature Industries: the role of University-Industry Collaborations. Research Policy, 42, 443453."

\title{
University-Industry Collaboration and Innovation in Emergent and Mature Industries in New Industrialized Countries
}

\author{
Isabel Maria, Bodas Freitas (corresponding author) \\ Rosane Argou, Marques \\ Evando Mirra de Paula e, Silva
}

\begin{abstract}
As the economies and indigenous technological capabilities of the new industrialized countries improve, national universities and public research organizations are expected to become increasingly important for supporting indigenous firms to move into more dynamic and highopportunity industries. However, the characteristics of collaboration with universities may be very specific depending on whether the industry partner is engaged in mature or emergent activities. In this study, we explore and discuss the role of university-industry collaboration for the development of innovation in mature and emergent industries in new industrialized countries. Evidence from 24 research groups in science and engineering departments in universities and public research organizations in Brazil provides preliminary empirical corroboration for the proposal that the contexts and role of university-industry collaboration in mature and emergent industries are diverse. Knowledge networks are underdeveloped in emerging industries, and public support for research projects is dispersed. This means that university research and development projects with firms in emergent industries are less likely than projects with firms in mature industries to be the result of academic initiatives and public calls for research projects, or to be wholly financed by major public research sponsors. In emergent industries, the role of students and firm employees is crucial for mediating between public research organizations and companies. The policy implications of these preliminary findings are discussed.
\end{abstract}

Keywords: University-industry collaboration; Emergent industries; New industrialized countries;

Science and technology policies 


\section{Introduction}

Newly Industrialized Country (NIC) governments are increasingly focused on fostering scienceindustry interactions and developing high-technology sectors (OECD, 2010; Gouvea and Kassicieh, 2007). Policy-makers in both developed economies and NICs have been concentrating on designing policies aimed at raising the quality of Public Research and Education Organizations (PREOs) research and training programmes, to make their role more entrepreneurial and of more benefit to national economic development, and to support the growth of high-technology activities (Eun et al., 2006; Wong et al., 2007). As the economies and indigenous technological capabilities of NICs improve, national PREOs are expected to become increasingly important for supporting indigenous firms to move into more dynamic and high-opportunity industries (Mathews and $\mathrm{Hu}$, 2007; Mazzoleni and Nelson, 2007). However, the innovation environments in mature and emergent industries differ considerably in terms of their market and technology turbulence, knowledge input characteristics, main search strategies for innovation inputs, role of networking, and collaboration for innovation development (Utterback and Abernathy, 1975; Tushman and Anderson, 1986; Robertson and Patel, 2007, von Tunzelmann, 2009). The characteristics of collaboration with universities may be specific to whether the industry partner(s) belongs to a mature or an emergent industry.

There is an extensive body of literature on university-industry collaborations and some of these studies examine cross-sectoral and disciplinary differences in the patterns of knowledge transfer between university and industry in developed countries and NICs (eg. Bekkers and Bodas Freitas, 2008; Dutrénit and Arza, 2010). However, to our knowledge, no work has been published on whether and how the establishment, content and organization of university-industry collaborations differ between emergent and mature industries. The present study tries to fill this gap. Its main objective is to provide preliminary empirical evidence on the specificities of university-industry relationships in mature and emergent industries in Brazil, one of the most important NICs. 
On the one hand, PREOs are often key actors in the process of industrial technological development and catch-up in specific industrial sectors (Mazzoleni, 2008). They can support the development of national technological capabilities and catch up, through the provision of training for scientist and engineers, support for personnel exchanges involving international researchers, experts and students, access to international research networks and new technologies, and advanced knowledge and skills in relevant science and engineering fields (Pavitt, 1998; Robertson and Patel, 2007). PREOs can provide support and advice to firms and governments on how to develop and employ technologies and avoid direct infringement of foreign Intellectual Property Rights (IPR) (Gouvea and Kassicieh, 2005; Mazzoleni and Nelson, 2007).

On the other hand, national institutional environments can provide incentives for firms active specifically in emerging and in mature industries and influence their performance. In particular, Chesbrough (1999) and Gittelman (2006) provide evidence of how the US institutional environment supports the development of new high-tech firms in biotechnology industry, and how the French and the Japanese institutional environments encourage the exploitation of the new market opportunities by large established firms in the pharmaceuticals industry.

The design and implementation of appropriate science and technology policies requires information about the context and characteristics of existing university-industry collaboration, and an understanding, especially, of the specificities of PREO-industry interaction in both mature and emergent industries. Employing the OECD's best practice in relation to technology transfer (e.g. creation of university Technology Transfer Offices (TTOs), definition of IPR, support for university spin offs) might be less effective for supporting university-industry collaboration and the growth of national high-technology sectors in NICs (OECD, 2005; Mowery and Sampat, 2005).

Given the scarce empirical evidence, especially in the case of NICs, this paper should be seen as a first step towards understanding whether and how the characteristics of university-industry interactions in mature and emergent industries differ, and as providing preliminary evidence to 
guide managers, and science and technology policy makers in NICs. The present study focuses on Brazil, where since 2003 policy has been aimed at improving national technological capabilities and supporting the development and growth of high-technology industries (Brazilian Government, 2003; Gouvea and Kassicieh, 2007).

Using data from semi-structured, face-to-face interviews with a sample of 24 coordinators of research departments in science and engineering faculties in universities, and in public research organizations, first, we analyse the context of science-industry collaboration, i.e. the motivations for, goals, main barriers to and facilitators of such collaboration in Brazil. Second, we examine the organizational changes undertaken by PREOs to promote improve 'entrepreneurial attitudes' among academic researchers. Third, we explore the specificities of university-industry collaboration in emergent and mature industries.

Our study contributes to the literature on the economics of knowledge transfer by highlighting differences in the forms and objectives of university-industry interaction in emergent and mature industries, and by providing preliminary evidence that certain knowledge transfer mechanisms are particularly crucial for mediating PREOs and firms in emergent industries.

The paper is organized as follows. Section 2 reviews the existing knowledge, and develops expectations about the characteristics and role of university-industry interactions in mature and emergent industries. Section 3 examines the specific institutional context of university-industry collaboration in Brazil. Section 4 presents the data and methodology used in this study. Section 5 discusses the motivations, object of and barriers to university-industry collaboration in Brazil, and the organizational changes implemented in PREOs to facilitate research cooperation with industry. Section 6 contrasts the characteristics of university projects involving firms active in emergent and in mature industrial and technological sectors. Section 7 discusses the policy and management implications of the preliminary findings and concludes the paper. 


\section{University-industry interaction and the technological challenges in mature and emergent industries}

In this section, we review the differences between mature and emergent industries in terms of the process of building industrial innovative capabilities, and discuss and develop expectations about the specific role of the university in the development of technological and innovative capabilities in industry, in light of these differences.

The innovative environments of mature low and medium technology industries and emergent high-technology industries differ considerably in terms of market and technology turbulence, and the characteristics of knowledge inputs. Consequently, search strategies for innovation inputs, the role of networking and collaboration for innovation development, and eventual innovative outputs also differ (Utterback and Abernathy, 1975; Tushman and Anderson, 1986; Strebel, 1987; Eisenhardt and Martin, 2000).

The emergent industry environment is characterized by strong competition in technology and product developments and strong market turbulence. As industries mature, and a dominant industry design emerges, technological uncertainty decreases and competition increasingly is based on cost, and incremental product innovations (Utterback and Abernathy, 1975; Strebel, 1987). Thus, technologies and markets evolve more quickly in emergent than in mature industries (Eisenhardt and Martin, 2000), but there is no evidence that innovation is more frequent in the former compared to the latter (McGahan and Silverman, 2001; Robertson and Patel, 2007).

Also, the types of knowledge inputs required for firms' innovation development, ways of accessing knowledge sources, and the results of firms' innovative efforts may be quite different across the industry lifecycle. Tacit and disembodied knowledge would seem particularly important for innovative activity in the early stages of the industry lifecycle and, consequently, personal contacts (i.e. telephone calls, participation in meetings, demonstrations) may be decisive for knowledge transfer (Audretsch, 1998; Mangematin and Nesta, 2001; Furman and MacGarvie, 
2009). Furman and MacGarvie (2009) show that in the early years of the US pharmaceutical industry, US universities supported the development of firms' research and development (R\&D) labs via training of scientific and technical staff and collaborative research. Given the importance of disembodied knowledge and personal contacts for innovative activity, geographic proximity often characterizes emergent industries (Prevenzer, 1997). In the early stages of an industry life cycle, new knowledge inputs and resources, such as university research, may enhance the agglomeration of innovative activity, while the new knowledge embodied in skilled workers favours clustering in all phases of the industry cycle (Audretsch and Stephan, 1996; Audretsch, 1998). Regardless of the characteristics of the knowledge, however, low absorptive capacity makes firms reliant on personal contacts (and thus proximity) to absorb external codified knowledge not related to its core competencies (Eisenhardt and Martin, 2000; Mangematin and Nesta, 2001).

In mature industries, firms tend to rely on embodied and codified knowledge to innovate (Robertson and Smith, 2008). Consequently, innovation development and maintenance of competitive advantage mainly involve the fusion of new and old technologies, which is a demanding problem-solving activity (Robertson and Patel, 2007; Freddi, 2009). In other words, innovation entails a development and problem-solving exercise of adaptation of new sophisticated technologies to the firm's market and technical competencies (Freddi, 2009; von Tunzelmann, 2009). Technology diversity seems to be a characteristic mainly of firms in mature industries (Granstrand et al., 1997; McGahan and Silverman, 2001).

Mature and emergent industries may differ also in their patterns of search for the knowledge and resources required to innovate. Grimpe and Sofka (2009) show that in high-technology sectors, firms search technological knowledge from universities and/or suppliers; while in mature industries, firms acquire market knowledge from customers or competitors. Robertson and Smith (2008) argue that, in mature industries, market knowledge provides the framework for the 
recombination and creation of knowledge through problem solving, via a range of activities and R\&D.

Networking and collaboration may play different strategic roles in the development of innovation over the industry lifecycle. In mature industries, innovation involves the 'management of knowledge bases distributed across a set of agents and institutions' (Robertson and Smith, 2008: 100; von Tunzelmann, 2009). In other words, firms need to rely on external knowledge sources for the development of non-core technologies (Pavitt, 1984; Morrison and Rabellotti, 2007; Grimpe and Sofka, 2009). In emergent industries, networking and collaboration may be crucial for accessing resources and searching for knowledge inputs (i.e. disembodied knowledge on science and technological development and market information) to develop specific new technologies and products (Powell et al., 1996; Koumpis and Pavitt, 1999).

In sum, as emergent and mature industries seem to differ in terms of the characteristics of the innovation development process rather than the level of the innovative activity, collaboration with universities may have specific characteristics depending on whether the industry partner is involved in mature or emergent activities. ${ }^{1}$ In mature industries, firms usually engage in frequent collaboration with universities to enlarge their general knowledge base and facilitate higher levels of technology integration with embodied knowledge. Also, since in mature industries product technologies and process technologies tend to overlap less (Granstrand et al., 1997; von Tunzelmann and Acha, 2005), PREOs are more likely to be able to support complex problemsolving related to the blending of new and old technologies and, consequently, to the development of new processes. Hence, university-industry collaboration is expected to be initiated through

\footnotetext{
${ }^{1}$ The ability efficiently to engage in and exploit collaboration with universities seems to be limited to firms with high research and organizational absorptive capacity, and especially companies active in high-technology and science-based industries (Fritsch and Lukas, 2001). The more basic the knowledge, the higher the absorptive capacity and learning investment required of firms to absorb the knowledge, regardless of the knowledge transfer channels (Eisenhardt and Martin, 2000).
} 
contacts with established knowledge and actor networks, and to focus on the manipulation of codified knowledge to produce new technical devices and instruments (Utterback and Abernathy, 1975; Tushman and Anderson, 1986; Mangematin and Nesta, 2001; Morrison and Rabellotti, 2007; Robertson and Smith, 2008).

In emergent industries, cooperation with universities is more often aimed at enhancing new knowledge development. Firms are more likely to collaborate with universities to access new knowledge developments and obtain scientific support for new product development (Powell et al., 1996; Lee, 2000). It is likely that this collaboration will be based on new and informal contacts with employees and students playing important roles (Lam, 2005; Balconi and Laboranti, 2006; Furman and MacGarvie, 2009). In terms of their objectives and organization, universityindustry collaboration may be more likely to focus on the use of disembodied knowledge and involve research students and to a lesser extent spin-offs creation (Powell et al., 1996; Koumpis and Pavitt, 1999; Lam, 2005), and its outcomes to be in the form of new instruments, technical devices and eventually patents and publications (Koumpis and Pavitt, 1999; Mangematin and Nesta, 2001; Furman and MacGarvie, 2009).

Starting from the evidence in the literature, the present study investigates whether and how university-industry collaboration in emergent high-technology sectors differs from universityindustry collaboration in mature sectors. We focus on the case of Brazil and in Section 3 examine the scientific, technological, collaborative and institutional university-industry contexts in that country.

\section{Context of university-industry collaboration in Brazil}

This section provides the background for the empirical research. In particular, we map the context of university-industry collaboration in Brazil, relying on secondary sources such as scientific 
publications, policy reports and national and international statistics. We start by providing some essential details on the recent evolution of scientific, technological and industrial performance in the Brazilian economy. We analyse average levels and patterns of firm interaction with PREOs for innovation development, and the institutional set up in Brazil highlighting the evolution of the legal and policy aspects of university-industry collaboration.

\subsection{Science and technology and competitive performance}

From the 1970s to the early 1980s, there was a significant shift in Brazil's revealed comparative advantage from primary goods to consumption goods and basic manufacturing. This situation then gradually reversed, and in the late 1990s it became more profitable to produce and export agricultural goods and raw materials than industrial goods, although Brazil was also 'exporting sophisticated industrial products, such as road vehicles, and aircrafts' (OECD, 2001: 142-143).

Brazil currently has good technological competences in some high and medium-high technology industries. It is close to or at the global innovation frontier in agriculture, biomass (ethanol), aeronautics and electric motors (Dahlman and Frischtak, 2005; Knight and Marques, 2008). Those industries that are at a long way behind the global innovation frontier include electronic instruments and information and communication technology equipment and related capital goods, chemical products (mainly fine chemicals), and pharmaceutical products (OECD, 2001; Dahlman and Frischtak, 2005). ${ }^{2}$

Despite Brazil's fairly good performance in some high-technology industries, during the 1990s, there were small shifts in the sectoral composition of its exports, and stagnation (decrease) in export performance, in contrast to China, Malaysia and Thailand (Montobbio and Rampa, 2005).

\footnotetext{
${ }^{2}$ The sectors at a moderate distance from the word frontier are agricultural machinery, buses, trucks and compact cars; auto parts and white goods (cooking stoves, refrigerators, washing machines, etc.); software (financial, administrative and security); and cosmetics.
} 
Brazil also lags behind other NICs in terms of science and technology inputs and scientific and inventive outputs (MCT, 2002; OECD, 2005).

In 2000, Brazil spent $1 \%$ of its GDP on R\&D, only slightly less than China (1.29\%) and Russia (1.24\%), and more than India (0.8\%) (MCT, 2002; OECD, 2005). In 2008, Brazil spent $1.13 \%$ of its GDP on R\&D, which was as much as Russia, but less than China (1.49\%) (MCT, 2009). Despite higher spending on public R\&D (53.5\% in 2008) than business research, $99.2 \%$ of Brazilian R\&D expenditure is in civil rather than military areas.

By the early 2000s, over half of China's scientists and engineers were employed in enterprises, which was a considerable change from the early 1990s when most of China's R\&D workers were employed in public research institutes. In Brazil, however, around $60 \%$ of its R\&D is conducted in PREOs (MCT, 2002, 2009; OECD, 2005). This concentration of research in PREOs rather than private firms, and Brazil's poor adaptation of public research funding and institutions to support growth in high technology opportunity sectors, combined with poor university-industry links, is often seen as the main cause of the stagnation in Brazil's export structure (MCT, 2002; OECD, 2005)

In terms of inventive output, Brazil registered 53 and 88 new patent applications in 1980 and in 1990 respectively, with the US Patent and Trademark Office (USPTO). This compares with China's 7 and 111. In 2007, registered patents for Brazil, China and Russia were respectively 385, 4,422 and 443 (MCT, 2009). Brazil also has fewer patents registered in national offices per unit of GDP compared to the developed countries (IBGE, 2003). Among the BRICS (i.e. Brazil, Russia, India, China and South Africa), foreign ownership of domestic patents is lowest in Brazil (35\%), followed by Russia (60\%), China (50\%) and India (40\%) (OECD, 2005).

For scientific output, in 2002 Brazil was ranked $17^{\text {th }}$ for number of ISI published papers (China $6^{\text {th }}$, Russia $9^{\text {th }}$, India $13^{\text {th }}$ ). Between 2001 and 2006, Brazil and China rose two places in this ranking and India went up by one place, while Russia lost five places (MCT, 2009). With 1.5 
researchers per 1,000 active habitants, Brazil lags behind some other NICs for numbers of scientists and engineers (MCT, 2002, 2009).

Although Brazil is a relative laggard in terms of science and technology inputs and outputs, large multinational firms already in Brazil refer to the quality and framework of their interactions with universities as the main reason for their willingness to increase their investment in R\&D in Brazil (ABDI and ANPEI, 2007). The ABDI and ANPEI (2007) study surveyed 48 multinational firms located in Brazil, in the automotive, information technology, chemistry, pharmaceutical, metallurgy, energy/electricity, electronics and telecommunications, food, hygiene, capital goods, semiconductors, and aluminium and metals industries. A majority of respondents (49\%) were subsidiaries of US multinationals, with French (10\%), Japanese (6\%), and others nationalities making up the remainder. Almost all interviewed firms (96\%) had R\&D investments in Brazil: $80 \%$ of these activities were related to the development of new products, processes and services, and $20 \%$ were devoted to research, $69 \%$ of which was experimental developmental research, $18 \%$ was applied research and $13 \%$ was research on adaptations to products for the Brazilian market.

\subsection{The innovative activity of Brazilian firms and their collaboration with universities}

According to the 2003 and 2005 Brazilian PINTEC innovation surveys, the innovative capability of Brazilian industry is quite high, $20 \%$ of firms had developed a new product, $27 \%$ had developed a new process and 13\% had developed both types of innovation (IBGE, 2005). In 2003-2005, some 7\% of innovative manufacturing firms (4\% in the period 2001 to 2003 ) had cooperated with other organizations to innovate. For over a third (38\%) of firms that cooperated for innovation, the innovation partner was a university. Most university collaborations were for $\mathrm{R} \& \mathrm{D}$ and product testing rather than technical assistance, industrial design, or other activities (IBGE, 2003, 2005). Collaboration with Brazilian universities is particularly important for the 
coke and oil, metals, electronic equipment, instruments, machinery, chemicals, pharmaceutical, and printing industries.

Universities are an important source of information for industrial innovation processes: $5 \%$ of innovative firms find university knowledge important and 5\% rate it very important. Universities are a particularly relevant source of knowledge for the pharmaceuticals, electronic equipment, instruments, chemicals, automobile, oil and coke, metals and beverages industries (IBGE, 2003, 2005).

In relation to public support for innovation, around $20 \%$ of innovative firms receive some type of public support, and 1\% received public support for collaboration with universities (IBGE, 2003, 2005). The share of innovative firms receiving public support for collaboration with a university is particularly high in the electronic equipment, machinery, metals, pulp and paper, coke and oil, pharmaceuticals, and transport equipment sectors (IBGE, 2005).

Firms in mature sectors (such as coke and oil, metals, pulp and paper) show high rates of collaboration with many external partners, including universities, and the highest levels of access to public financial support for collaboration with academia (PINTEC, 2003, 2005). This may be related to the fact that, historically, these industries played an important role in Brazil's catchingup process (OECD, 2001; Dahlman and Frischtak, 2005).

\subsection{The evolution of policy measures supporting university-industry collaboration}

The science and technology infrastructure in Brazil developed alongside the country's industrialization process, especially after the 1940s. Following the establishment of the older universities in the late 1920s and 1930s, research institutes were set up to resolve technical problems in different technological areas in the 1940s. In the 1950s the national research council was created and provided support for scientific and technological development and promoted Brazil's industrialization through the transfer of new technologies. In the 1960s, additional 
institutions and administrative resources were added and in 1985 the Ministry of Science and Technology was created (Velho and Saenz, 2002; MST, 2010). The presence of these institutions notwithstanding, the centrality of innovation in industry and competition policies, and the emphasis on technology transfer in science and technology policies is a relatively recent phenomenon (Velho and Saenz, 2002; Dagnino and Gomes, 2003). In 2003, industrial innovation became an explicit government objective supported by the launch of Brazil's Industrial, Technological and Trade Policy (PITCE). The 2008 White Paper on Industrial Policy for the Development of Production strengthened government support for industrial innovation. In 2007, the Science and Technology Plan (PACTI) stressed the importance of creating public support for innovation in industry, and an increased role for universities in this process (Silva and Oliveira, 2007; Erawatch, 2009).

With regard to technology transfer activities, public incentives for university-industry collaboration through public research sponsors were introduced in the 1970s in the form of collaborative Masters and Doctoral projects. During the 1970s, public support for universityindustry collaboration was focused on the metals industry, but was later extended to such industries as agriculture, offshore petroleum exploration and aeronautics (FINEP, 2005). Since the 1980s, and especially in the 1990s, public support for university-industry collaboration has grown hugely (Velho and Saenz, 2002) and in the 2000s, public support for university-industry collaboration in high-technology sectors is being encouraged in part because it is focused on firms' value chains rather than branches of activity (FINEP, 2005; Silva, 2007).

Government's efforts to facilitate the institutional set up of university-industry collaboration, which dates back to the 1970s, has been strengthened. In 2001, the Innovation law set the general regulations for the IPR on the results of government financed research, for shared infrastructures, and for mobility of researchers from the national state universities and research centres to the private sector (Invernizzi, 2005). In November 2005, Law 11.196, 21, known locally as the Good Law (Lei do Bem) provided for large financial incentives to firms (tax deductions) for private 
investment in innovation, contracting of doctoral students, and filing of patents, among other things (MCT, 2009).

In sum, despite its overall good industry innovation performance, Brazil is lagging behind in scientific and technological outputs, its export performance is stagnant, and in some medium and high-technology industries levels of competitive and technological advantage are low. Brazil's policy-makers are concerned with supporting the development of technological and innovative capabilities in national firms, growing the high-technology industries, and involving PREO in the achievement of these goals. Some OECD best practice in providing incentives for industry R\&D and interaction with universities have been adopted. The critical issues are the motivations for, and objectives and organization of university-industry cooperation since it is seen as an important means to foster innovation performance and increase the market competitiveness of Brazilian industry, especially in the emergent technology-intensive sectors.

\section{Method}

The objective of our research is to examine whether and how university collaboration with emergent and mature industries differ in Brazil. The analysis needs to be contextualized. Hence, we also analyse academics' motivations and the barriers to collaboration with industry generally, and PREO policies to foster collaboration with industry, and the reactions of academics to these efforts.

For the empirical part of the analysis, between April and August 2007, we carried out semistructured face-to-face interviews with the coordinators of 24 research groups at various universities and PREOs, in several different scientific and engineering areas. We conducted eight interviews with research departments in Physics, seven in Chemistry, six in Engineering, and three in Mathematics. 
Interviewees were asked to provide some general information on their department and its relationships with industry. They were also asked for specific and detailed information on one current or recently completed collaborative project with industry. Since the interviews were semistructured this allowed us to collect information on the characteristics of research departments (i.e. size, staff, papers, patents), their collaborations with industry (i.e. objectives, forms of research management, facilitators and barriers), and the organizational efforts of PREOs to support collaboration with industry. We collected detailed information for one specific project conducted in collaboration with industry, for each research department. This included information on origin, form of management, financing and output (Bozeman, 2000; Bercovitz and Feldman, 2006).

To categorize projects into emergent and mature industries, we focused on the activities of participating firms rather than on the project objectives. However, this classification is not perfect. For example, several authors argue that there is no match between products and technologies and for this reason categorization of industries into high-technology and low-technology is problematic (i.e. firms operating in low technology industries also use sophisticated technologies) (Granstrand et al., 1997; von Tunzelmann and Acha, 2005; von Tunzelmann, 2009). However, the combination of old and new technologies seems more relevant for mature industries, as discussed in section 2.2, while the search for new knowledge bases seems more applicable to emergent industries (McGahan and Silverman, 2001; Freddi, 2009). Therefore, we classify emergent industry projects as those where the main activity of the participating firm is related to the production of science-based technologies and products (i.e. new industries) and mature industry projects as those where the participating firm was not the producer of the technologies but the 'knowledgeable' user of the technologies (i.e. firms active in long established industries that are identified by national and international statistics, Robertson and Patel, 2007).

Of the 24 collaborative projects surveyed 10 involved firms active in emergent industries, i.e. firms involved in the production of information technology (3), biotechnology (5) or 
nanotechnology (2) and products. Among the projects with mature industries, five projects involved firms in the oil industry (two with Mathematics departments), three involved equipment and machinery firms; two involved chemical firms; one was with a firm in the textile industry, one with a firm in the electricity sector, and one was with a telecommunications firm.

Using the information collected from the interviews, in Section 5, we examine the specificities of PREO collaboration with industry. We examine the motivations and objectives of, the barriers to and the facilitators of university-industry collaboration. We analyse the auxiliary services provided by PREOs to promote researchers' collaboration with industry, and the views of researchers on the effectiveness of those services. Section 6 focuses on one specific collaborative project in each research department. We explore the differences in promotion, finance, objectives and outcomes between projects undertaken with firms in emergent industries and those undertaken with firms in more mature industries. The main part of the analysis is based on qualitative data on the characteristics of emergent and mature collaborative projects, reported by research department coordinators, complemented by the results of cross tabulations, ranked Spearman's correlation coefficients and Mann-Whitney non parametric t-tests in order to further highlight the qualitative findings reported in the text.

\section{University-industry collaboration in Brazil}

\subsection{Researchers' perceptions of the motivations for and barriers to collaboration with industry}

Table 1 ranks of the main motivations for research departments that engage in collaborations with industry. A higher loading indicates a less important motivation.

[Insert Table 1 about here] 
Development and transfer of new technology and development of new knowledge were the main motivations for collaborating with industry identified by the research departments we surveyed. Support for the innovative capabilities of national firms was seen as the least important reason for collaborating on with industry, reflecting the presence of an academic bias towards scientific developments.

The ranking of the motivations to collaborate with industry reflects the objectives of universityindustry collaboration. Table 2 shows that the most common objective of collaboration with industry is the development of a new product or process and that improvement to an existing product or process is a very poor motivation for university-industry collaboration.

[Insert Table 2 about here]

We asked research coordinators, based on their experience of cooperation, to categorize different factors into barriers to and/or facilitators of university-industry collaboration. Table 3 reports the number of research departments that identified each factor as a barrier to or a facilitator of collaboration with industry.

[Insert Table 3 about here]

Proximity, public research sponsorship, TTOs and other organizations supporting knowledge transfer, and tax incentives, were seen as facilitators of university-industry collaboration while high technical uncertainty, bureaucracy imposed by the sponsor, the time required by the firm, and the long-time frame of collaborative projects were seen as barriers to the completion and success of collaborative research projects.

It is interesting that ownership of project results and university support for project management are grey areas given that a similar number of departments rated them as enhancing and inhibiting university-industry collaboration. The issue of ownership of collaborative project results can 
affect PREOs' research activity because researchers may need to delay publications and comply with specific disclosure procedures. On the other hand, it may produce additional remuneration. Researchers often receive assistance from PREO administrations or TTOs for dealing with the contractual side of collaborations. However, these services may not fit fully the needs and routines of researchers. In the next subsection, we analyse the incentives created by PREOs for academic entrepreneurship.

\subsection{Institutional incentives for academic entrepreneurship and interaction with industry}

In order to understand the institutional efforts involved in organizational change in PREO to facilitate university-industry collaboration, we asked research coordinators to identify whether their organizations provided lists of services to support university-industry collaboration, and whether these services addressed the main barriers to university-industry collaboration. Figure 1 shows the number of PREOs that offer specific support for collaboration with industry, the number of respondents that rated provision of these services as important to overcome the barriers to collaboration, and the number of respondents that had not benefited from these services, but acknowledged their value.

[Insert Figure 1 about here]

Responses suggest that the most common services available to university researchers are related to the contractual and financial aspects of university-industry interaction: legal advice; procedures for acquiring materials/equipment; financial monitoring and control; drawing up the contract; keeping accounts. These contractual and financial services are recognized as supporting collaboration with industry and overcoming the barriers identified. Services such as screening of R\&D sponsorship available for industry collaboration, development of industrial contacts, and management of collaborative projects are provided by more than half of the organizations surveyed. Establishment and management of industry collaboration are not always seen by the 
beneficiaries of knowledge as facilitating its transfer; however, researchers in organizations that did not offer these services acknowledged their importance for overcoming certain barriers.

Personal and professional incentives and help in diffusing research to industry are not widely offered by PREOs in Brazil. However, university researchers consider that the provision of services to improve industry awareness of university research and professional incentives for collaboration would encourage higher levels of cooperation.

Advice on patenting is rarely available and was ranked lowest among the services that might help address the barriers to collaboration with industry. This perhaps is related to the passing in 2001 of the Innovation Law, which set the rules for IPRs on the results of government financed research. Thus, there is an automatic legal framework for IPRs issues related to government funded research.

Overall, our evidence suggests that university-industry collaboration focuses more often on the development of new products and processes than improvements to existing ones or the provision of services. Brazilian academics' collaboration with industry is related mainly to the development and transfer of new technology and new knowledge. The length and technological uncertainty, and the bureaucracy related to conducting projects were the most frequently cited barriers to collaboration with industry, while direct and indirect public support and, and to a lesser extent TTO support were ranked highest for supporting collaboration. Studies in developed countries, mainly European countries and the US, report similar motivations for and similar barriers to university collaboration with industry (Lee, 2000; Hall et al., 2001; Lam, 2005).

The evidence from this study suggests also that, following trends in the OECD countries, most Brazilian PREOs have introduced incentives for industry collaboration through the provision of contractual and financial advice and services, both of which are highly valued by researchers. Most PREOs provide some services to support the establishment and management of industry 
collaboration. These are seen only as facilitating researchers' interaction with industry; the researchers do not benefit from them directly. Despite fairly good provision of auxiliary management services, Brazilian PREOs generally have been slow to provide services to address information and contact gaps between industry and universities. Research coordinators would welcome the introduction of services to raise industry awareness about university research, and to map industry's technological capabilities and needs. Moreover, they claim the revision of the career rules in order to create incentives to collaborate with industry, and argue that the delay in adapting the incentive system of PREOs is a major barrier to collaboration with industry.

\section{University-industry collaboration: What are the differences in projects established with firms in emergent industries?}

To achieve a more rounded view of the process of university-industry cooperation, we asked research department coordinators to identify a specific collaborative project and describe its design and main results. ${ }^{3}$ Ten of the 24 projects analysed involved firms in emergent industries: 5 in biotechnology, 3 in information technology and 2 in nanotechnology. Our analysis of the differences between projects involving firms in emergent and mature industries yielded some

\footnotetext{
${ }^{3}$ It could be argued that departmental characteristics affect the likelihood of engaging in collaboration with emergent industries. In this study, we analyse the differences in the content and organization of projects undertaken with firms in emergent and in mature industries, rather than on how the different characteristics of the research departments involved influence the likelihood of their collaborating with firms in emergent industries, which would require different data and method. Out of curiosity, we examine the correlation between some department characteristics and reporting a project with an emergent industry firm. In terms of year of foundation of the department, number of researchers and number of on-going collaborative projects with industry, departments that identified a project with an emergent industry do not differ from those that reported a project with a mature industry. However, they differ for number of patents issued and licensing agreements. Departments with a smaller number of patents and larger numbers of licensing agreements were significantly $(10 \%)$ more likely to describe a collaboration with a firm in an emergent industry. Also, a larger share of collaborative projects with emergent industries was reported by Physics, with Engineering departments reporting significantly fewer.
} 
interesting results. Table 4 reports the number of projects that addressed listed objectives, the origins of the collaborative projects, funding sources, and outputs, for the whole sample and for the sub-sample of projects undertaken with firms in emergent industries, along with the respective non-parametric Spearman' correlation coefficients and the results of Mann-Whitney T-tests.

[Insert Table 4 about here]

In relation to project objectives, from the full sample of 24 projects, new product development applied to 14 projects and new process development for 10 projects. Four projects were aimed at the development of a new product and a new process, of which three were undertaken by Chemistry research departments. Only three projects focused on improvements to existing processes. For the sub-sample of projects undertaken with firms active in emergent industries, the objective of a collaboration was less likely to be an improved process and to a lesser extent the development of a new process. Relatively more projects with firms in emergent industries are aimed at the development of a new product and training of employees, than projects with firms in mature industries (but we found no statistically significant difference).

If we compare the origins of collaborative projects in mature and emergent projects, we find important differences. In the full sample, a third ( 8 projects) were originated by firms, which identified needs and expressed interest in collaborating with the research departments in question to support their internal R\&D. Six projects were the result of an idea formulated by a PREO, where the research groups identified and contacted potential firms to support the development of a new process or improve an existing process. The other cases were less clear cut and were based on a combination of informal and professional contacts, applications to R\&D sponsors, and doctoral research projects. If we compare mature and emerging industries for the origins of collaborative projects, we see that, in the case of emergent industries, relatively fewer projects were proposed by PREOs to address an industry R\&D need. Also, fewer emergent industry projects were based on a proposal to apply for research funding. Half of the projects with firms in emergent sectors were initiated by firms or students. Students, and especially postgraduate students, are the major 
link between PREOs and emergent industry firms because they propose new projects and because they go on to work in firms and are aware of the importance of PREO for supporting product development.

The main source of finance, among the full sample of projects analysed, is FINEP (Funding for Studies and Projects) which financed 11 projects, followed by CNPq (National Council for Scientific and Technological Development), which financed 8 projects. The state funding agencies (FAPs) financed two projects. Eighteen projects also received funding from other private or public sources, but only six projects were implemented without co-funding from FINEP, CNPq or FAPs. CNPq is the national research council, under the Ministry of Science and Technology, and is responsible for promoting science and technology development and training. FINEP is a national body within the Ministry of Science and Technology, and is responsible for managing national sectoral funds and for supporting innovation and technology development in firms, universities and other research organizations. FAPs are state funding organizations which promote and invest in $\mathrm{R} \& \mathrm{D}$, training of scientists and engineers, and innovation. Of the 10 emergent industry projects, nine received funding from other sources, four were fully financed by these other sources and six were co-financed by FINEP, CNPq, and by FAPES. Relatively more emergent industry projects are financed by other sources, especially other public sources (including scholarships for $\mathrm{PhD}$ studies), compared to projects in mature industries. The main public R\&D sponsors, especially FINEP and CNPq, seem to articulate their funds with other specific funds made available under other public research or innovation programme lines, resulting in a higher number of different financing sources for emergent projects than for mature projects.

Furthermore, we asked about the outputs of the 24 collaborative projects. In the whole sample, papers and post-graduate theses are the most frequent outputs of collaborative research, followed by new products, patents and new processes. Books, improved processes, licensing and spin off creation are the least frequent outputs of university- industry collaborative projects. University 
projects with firms in emergent industries result in books and improved processes more frequently than projects with firms in mature industries. Relatively more emergent industry projects have new processes, student theses, and new products as outputs, however, there are no statistically significant differences. Improved and new processes are more likely to be by-products since, as already noted, these were among the least important objectives of collaborative projects with emergent industries. Thus, projects with emergent industries achieve a slightly higher average number of outputs than projects with mature industries. Licensing is the only outcome with a negative, but not significant correlation coefficient of emergent projects.

Finally, for initiating a new project after completion of a previous project, we find that in the full sample 11 projects led to a new collaborative project. Of the ten projects with emergent industry firms, two led to a new collaboration, which suggests that the possibility of a new project following a previous collaboration is small for collaboration with firms in emergent industries.

In line the literature, our analysis suggests that knowledge and actor networks seem to be less well developed in emergent than in mature industries. Projects with firms in emergent industries are less likely to be initiated by a PREO or an informal, professional PREO researcher contacts network. Calls for collaborative research proposals for research funding are less likely to be the motivation for university-industry collaboration in emergent industries. Instead, collaborative projects with firms in emergent industries are more likely to be initiated by current graduate and post-graduate students, who may propose specific projects to be carried out in collaboration with firms in emergent industries, or by firm graduate employees. Hence, while informal and personal contacts are important in emergent industries, the network depends heavily on participation of students and former students rather than on the incentives created by public funds, professional experience or academic research agendas. Thus, collaborations with emergent industry firms tends to be the result of the two traditional PREO missions of teaching and research, rather than the 
third mission ${ }^{4}$ (Etzkowitz, 1998) of support for economic development. Moreover, collaborative projects with emerging industry firms are more likely to combine financing from the main public research sponsors and other (mainly public) sources, to address specific developments in a limited group of technologies, often related to doctoral projects.

Projects with firms in emerging industry firms focus more on the development of new products, and employee training than on process improvements, and show a slightly higher average number of outputs than projects with firms in mature industries. This higher performance in terms of output may be the result of technological spillovers from these projects, which in addition to the main goal of product development, often achieve complementary new or improved processes. Books and theses are more frequent outputs in these projects than in projects with mature industry firms, due to the involvement of postgraduate students in many projects. However, continued collaboration after completion of a project is less common in emerging industry firms. This might be related to the fact that students often act as the mediators in these one-off collaborations: the trusting relationships between university and firm required for collaborative projects may not be achievable on the basis of a single project. Another explanation might be that public funding for $\mathrm{R} \& \mathrm{D}$ collaboration in emergent technologies may be difficult to locate as sources of funding are spread across several public organizations and policy programs.

\footnotetext{
${ }^{4}$ Note that there is no consensus on the concept of 'entrepreneurial university' and the analytical frame of 'the three university missions' proposed by Etzkowitz (1998) Many authors claim that it is the traditional activities of universities that most often complement entrepreneurial activities (Azoulay et al., 2007). In particular, undergraduate teaching, specialist masters courses for professionals, and academic and research training activities represent the fulfilment of the traditional university missions and also, to an extent, fulfilment of the third mission in stimulating the local economy through the training of future local employees, attraction of foreign students, and technology leadership (Laredo, 2007). Others argue that incentives for entrepreneurship should not be imposed on universities because it may affect the incentives for academics to engage in high quality research and teaching (Welsh et al., 2008; Dosi et al., 2006). Specific levels of involvement of universities in research, teaching and economic development vary according to the disciplinary focus, the types of students and the academic characteristics of universities (Laursen et al., 2010).
} 


\section{Discussion and Conclusions}

This study provides preliminary empirical evidence on the role and specificities of collaboration between PREOs and firms active in mature and emergent industries. We relied on studies in the literature and data collected through semi-structured interviews with 24 research group coordinators in science and engineering departments in PREOs in Brazil. Brazil is a NIC which has achieved high technological competence in certain high and medium-high technology sectors although it is lagging behind other NICs for scientific and technological performance (Montobbio and Rampa, 2005; IBGE, 2005; MCT, 2009). Given the acknowledged importance of universityindustry collaboration in the process of catching up in some sectors, including in Brazil (Mazzoleni and Nelson, 2007), we focused on the context of university-industry collaboration and then explored the specificities of this collaboration in Brazilian emergent high-technology industries in order to get a better understanding of how PREOs can support the development and growth of these industries.

Our study provides several insights. Informal and professional networks of PREOs and industry researchers in emergent activities are underdeveloped compared to the networks of mature industries. Moreover, national public support for university-industry collaboration in emergent industries is dispersed across different public organizations/ programmes. Therefore, in contrast to projects with firms active in mature industries, university $R \& D$ projects with firms active in emergent industries are less likely to be the result of academics' initiative and public research sponsors' calls for projects, or to be wholly financed by the major public research sponsors. Consequently, in emergent industries, it is students and firm's employees mediation between PREOs and firms rather than calls for collaborative projects that matter. PREO collaboration with emergent industry firms tends to focus on new product development, and employee training. Thus, our results suggest that PREO collaboration with emergent industries results mainly from the university traditional missions of teaching and research. Our analysis suggests also that 
collaboration with emergent industries is relatively more productive than collaboration with mature industry firms, because besides their main objective of new product development and training, they often achieve new or improved processes and books as complementary outputs.

It should be noted that this study has some limitations. First, it focuses on data collected from the university partner in the collaboration. It would be interesting to investigate the perspectives of industry in order to better understand the motivations for and barriers to collaborating with universities, and to capture industry differences in these motivations between emergent and mature industry firms. This is a common limitation since very few contributions in the universityindustry literature use data on both collaboration partners (Bekkers and Bodas Freitas, 2008 is one of the very few exceptions). Second, in order to extract detailed information on the characteristics of collaborations, our analysis was carried out using unique project level data collected from interviews with PREO directors and, necessarily, relies on a small sample of observations. This restricts the type of statistical analysis that is possible, and makes our results exploratory. Further research is needed to expand the size of the sample and to exploit different methods of enquiry and analysis. Third, this is a single country study. It would be interesting to analyse the extent to which these results can be generalized to other countries given that cross-country differences may exist between specific academic, industrial and political contexts. Some studies show that some economies have institutional systems that create positive complementarities for new business firms while in others the incentives are aimed at and absorbed by large established firms (Chesbrough,1999; Gittelman, 2006).

Finally, we would stress that the national research system on its own cannot foster the emergence and growth of technological capabilities, especially in high-technology industries. On the one hand, a focus on national policies targeting high-technology industries may be ineffective because, combined with the technological characteristics of these industries, policies may work to reinforce over-investment and excessive competition (i.e. abnormal excess capacity, high sunk costs and sustained subnormal profits), especially because national governments worldwide tend 
to target the same high-technology industries (Brahm, 1995). Moreover, the value of university collaboration seems to depend on the firms' knowledge bases (Giuliani and Arza, 2009). On the other hand, the development of dynamic emergent industries involves a process of capability building within firms, which requires upgrades to internal skills, production and R\&D activities (Lall, 1992, 1993; Koumpis and Pavitt, 1999; Gittelman, 2006). This requires government policies that target the development of human skills and technology infrastructures and the creation of macroeconomic stability, selective industry incentives and market and non-market institutions such as laws, IPRs, standards, codes of good business practice, and so on (Dahlman et al., 1987; Lall, 1992, 1993; Gouvea and Kassicieh, 2005, Storm, 2008). These issues, which are not addressed in this paper, are very important for investment and development in high-technology industries

Bearing in mind these limitations, our evidence prompts some questions about the role of PREOs for the development and growth of emergent industries, and allows some policy and managerial implications to be drawn which may be valid for both Brazil and other countries with similar industrial structures.

Our evidence suggests that Brazilian PREOs are supporting innovation and technological development in mature sectors where they have established contacts and to which the main public research sponsorship seems to be tailored. In other words, technological opportunities, which could benefit from high demand from mature industries in Brazil (Robertson and Patel, 2007), seem to be appropriated mostly by large firms in mature sectors rather than supporting the growth of emergent sectors. These results raise questions about the effect of increased national research council budgets to support the development and growth of emergent, sophisticated industries, and to overcome economic and technological stagnation. Revision of the implementation of national public research funding for emergent industries and the creation of information gateways to public (and private) sources of financing for R\&D may be needed. 
To stimulate the development of knowledge flows and the level of actors' engagement with emergent industries, which our evidence shows are less developed than in mature industries, public support for the creation of institutions and centres of excellence may be required to foster growth and build R\&D networks around specific technologies and sectors alongside the creation of virtual networks of knowledge and actors for the production and use of new technologies. In addition to network building efforts and the mapping of technological capability in industry and universities, the revision of the incentive frameworks and career rules of researchers and lecturers, referred to by our interviewees, may help to raise the quality of research and training in basic sciences and encourage university-industry interaction.

In addition to national or federal policy efforts, universities may encourage the building of knowledge networks with industry, especially emergent industries. The technology transfer services in PREOs could develop strategies to map industry actors and needs in emergent sectors and diffuse academic expertise to this population of firms. PREOs may be able to exploit specific national technology programmes to support the development of excellent competences by providing extra incentives for interaction with industry and for applied research oriented to indigenous user industries (Ekboir, 2003; Wong et al., 2007). They may be able to leverage national policies to improve the quality of research and education by creating specific incentives (Etzkowitz et al., 2005; Eun et al., 2006).

The evidence provided in this paper also points to the importance of graduate and post-graduate students and firm employees mediating between academia and emergent industry firms, and the predominance of research as a motivation for collaboration with industry. It highlights the importance of the university teaching and research missions for interaction with emergent industries. It also raises questions about the effectiveness of adopting OECD technology transfer best practice, which increasingly are focused on the commercialization of knowledge, for the emergence and growth of emergent industries. In NICs, firms have particular technology 
requirements, including the need to master basic science and apply existing knowledge and technologies (e.g. Pavitt, 1998; Robertson and Patel, 2007). University researchers tend to collaborate with industry for research rather than only financial reasons (Lee, 2000; Lam, 2005; Dutrénit and Arza, 2010). Thus, in line with previous studies, we would argue that national policy-makers and PREOs need to be aware of the importance of education and research for economic development (Laredo, 2007; Welsh et al. 2008) and public policies to create incentives for university-industry collaboration need to be aligned to academics values if they are to be effective.

Our findings have some implications for innovation management in firms in emergent industries. The literature argues that locating university knowledge and public support for innovation is difficult. Our evidence shows that university-industry collaboration in emergent industries is more likely to be initiated by current and former students and to be financed from several sources including postgraduate grants. Hence, in these industries, interaction with universities may be facilitated if firms invest in networking with university by identifying talented students before they graduate and sending employees to universities for training. Firms should not restrict their search for research funding to traditional research sponsors or funds for collaborative research projects; they should search for different types of funding, including funding for doctoral projects, from public and private institutions. Given the difficulty involved in accessing the major funders of university collaboration, collaboration with capable customers in mature industries may provide access to public funds and university research. 


\section{References}

ABDI and ANPEI (2007). Projeto: Atração de Investimentos de Pesquisa e Desenvolvimento de Empresas Transnacionais. Associaçao Nacional de Pesquisa e Desenvolvimento, Brasil.

Audretsch, D. B. and Stephan, P. (1996), 'Company-Scientist Locational Links: The Case of Biotechnology', American Economic Review, 86(4), 641-52.

Audretsch, D.B. (1998). 'Agglomeration and the location of innovative activity', Oxford Review of Economic Policy, 14 (2), 18-29

Azoulay P., Ding W., and Stuart T. (2007). 'The determinants of faculty patenting behavior: Demographics or opportunities?', Journal of Economic Behavior \& Organization, 63, 599-623.

Balconi, M. and Laboranti, A. (2006), 'University-industry interactions in applied research: the case of microelectronics', Research Policy, 35, 1616-1630.

Bekkers, R. and Bodas Freitas, I.M. (2008), 'Analysing knowledge transfer channels between universities and industry: To what degree do sectors also matter?', Research Policy. 37, 1837-1853.

Bercovitz, J. and Feldman, M., (2006), 'Entrepreneurial Universities and Technology Transfer: A Conceptual Framework for Understanding Knowledge-Based Economic Development', The Journal of Technology Transfer, 31 (1), 175-188

Bozeman, B. (2000), 'Technology Transfer and Public Policy: A Review of research and Theory', Research Policy, 29, 627-655.

Brahm, R. (1995), 'National Targeting Policies, High-Technology Industries, and Excessive Competition', Strategic Management Journal, 16, 71-91.

Brazilian Government (2003). "Diretrizes de Política Industrial, Tecnológica e de Comércio Exterior" Downloaded in $22 / 05 / 07$ from http://www.abdi.com.br/abdi redesign/publicacao/download.wsp?tmp.arquivo=107

Chesbrough H.W. (1999). The organizational impact of technological change: a comparative Theory of National institutions factors. Industrial and Corporate Change, 8 (3) 444-484.

Dagnino, R. and Gomes, E. (2003), 'A relação universidade-empresa: comentários sobre um caso atípico', Gestao e Produçao, 10 (3): 283-292

Dahlman C. J. and Frischtak, C. (2005), 'Os Desafios para o Brasil da Economia do Conhecimento: educação e inovação em um mundo crescentemente competitivo'. In (ed) Reforma Política e Economia do Conhecimento: dois projetos nacionais. José Olympio: Rio de Janeiro.

Dahlman C. J., Ross-Larson, B. and Westphal, L. E. (1987), 'Managing Technological Development: Lessons from the Newly Industrializing Countries', World Development, 15, 759-775

Dosi, G., Llerena, P. and Labini, M.S. (2006), 'The relationships between science, technologies and their industrial exploitation: an illustration through the myths and realities of the so-called 'European Paradox", Research Policy, 35(10), 1450-1464. 
Dutrénit, G., and Arza, V. (2010), 'Channels and benefits of interactions between public research organisations and industry: comparing four Latin American countries'. Science and Public Policy, 37 (7), 541-553.

Eisenhardt K. M. and Martin, J. A. (2000), 'Dynamic capabilities: what are they?', Strategic Management Journal, 21, 1105 - 1121

Ekboir J. M. (2003), 'Research and technology policies in innovation systems: zero tillage in Brazil', Research Policy, 32, 573-586

Erawatch (2009), National Profiles http://cordis.europa.eu/erawatch/index.cfm?fuseaction=ri.content\&topicID=5\&countryCode=BR\&pa rentID=4, retrieved September 2009.

Etzkowitz, H., 1998. The norms of entrepreneurial science: cognitive effects of the new universityindustry linkages. Research Policy 27, 823-833.

Etzkowitz H., Mello, J. M. C. and Almeida, M. (2005), 'Towards "meta-innovation” in Brazil: The evolution of the incubator and the emergence of a triple helix', Research Policy, 34, 411-424

Eun J-H., Lee, K. and Wu, G. (2006), 'Explaining the "University-run enterprises" in China: A theoretical framework for university-industry relationship in developing countries and its application to China' Research Policy, 35, 1329-1346

Furman, J. L. and MacGarvie, M. (2009), 'Academic collaboration and organizational innovation: the development of research capabilities in the US pharmaceutical industry, 1927-1946', Industrial and Corporate Change, 18(5), 929-961.

FINEP (2005), Brazilian Innovation Agency Report 2005. http://www.finep.gov.br/english/FINEP_folder_ingles.pdf

Freddi, D. (2009), 'The integration of old and new technological paradigms in low- and medium-tech sectors: The case of mechatronics', Research Policy, 38, 548-558

Fritsch, M. and Lukas, R. (2001), 'Who cooperates on R\&D?', Research Policy, 30, 297-312.

Gittelman, M. (2006). National institutions, public-private knowledge flows, and innovation performance: A comparative study of the biotechnology industry in the US and France. Research Policy, 35, 1052-1068.

Giuliani, E. and Arza, V. (2009). What drives the formation of 'valuable' university-industry linkages?: Insights from the wine industry. Research Policy, 38(6), 906-921.

Gouvea, R. and Kassicieh, S. (2005), 'Using resources in R\&D policy planning: Brazil, the Amazon and biotechnology', Technological Forecasting \& Social Change, 72, 535-547

Granstrand O., Patel, P. and Pavitt, K. (1997), 'Multi-technology corporations: why they have “distributes" rather than "distinctive core" competencies', California Management Review, 39, 8-25

Grimpe, C. and Sofka, W. (2009), 'Search patterns and absorptive capacity: Low- and high-technology sectors in European countries', Research Policy, 38, 495-506 
Hagedoorn, J. (1996), 'Trends and Patterns in Strategic Technology Partnering Since the early Seventies', Review of Industrial Organization, 11, 601-616

Hall, B. H., Link, A. N. and Scott J.T. (2001), 'Barriers Inhibiting Industry from Partnering with Universities: Evidence from the Advanced Technology Program', The Journal of Technology Transfer, 26, 87-98.

IBGE (2003), Pesquisa de inovação tecnologica. IBGE, Instituto Brasileiro de Geografia e Estatistica, http://www.pintec.ibge.gov.br/ , last retrieved August 2009

IBGE (2005), Pesquisa de inovação tecnologica. IBGE, Instituto Brasileiro de Geografia e Estatistica, http://www.pintec.ibge.gov.br/ , last retrieved August 2009

Invernizzi, N. (2005) 'Science and technology policy in transition: new challenges for Cardoso's legacy', International Journal Technology and Globalisation, 1 (2), 162-184.

Knight, P. and Marques, R. M. (2008), 'Closing the Technology Gap'. In: Haar J. and Price (ed) Can Latin America Compete? Confronting the Challenges of Globalization. p. 99-119. Palgrave Macmillan: New York.

Koumpis, K. and Pavitt, K. (1999), 'Corporate activities in speech recognition and natural language: another "New Science"-based technology', International Journal of Innovation Management, 3, 335366.

Lall, S. (1992), 'Technological Capabilities and Industrialization', World Development, 20, 165-186

Lall S. (1993), 'Understanding Technology Development'. Development and Change, 24(4), 719-753

Lam, A. (2005), 'Work Roles and Careers of R\&D Scientists in Network Organizations', Industrial Relations, 44(2), 242-275.

Laredo, P. (2007), 'Revisiting the Third Mission of Universities: Toward a Renewed Categorization of University Activities?' Higher Education Policy, 20, 441-456.

Laursen, K., Reichstein, T., and Salter, A. (2011), 'Exploring the effect of geographical proximity and university quality on university-industry collaboration in the UK', Regional Studies, 45(4), 507-523.

Lee, S. Y. (2000), 'The Sustainability of University-Industry Research Collaboration: An Empirical Assessment', The Journal of Technology Transfer, 25(2), 111-133.

Mangematin, V. and Nesta, L. (1999), 'What kind of knowledge can a firm absorb?', International Journal of Technology Management, 18, 149-173

Mathews, J. A. and Hu, M-C. (2007), 'Enhancing the Role of Universities in Building National Innovative Capacity in Asia: The Case of Taiwan', World Development, 35, 1005-1020

Mazzoleni, R.(2008), 'Catching Up and Academic Institutions: A Comparative Study of Past National Experiences'. Journal of Development Studies, 44 (5), 678 - 700

Mazzoleni, R. and Nelson, R. R. (2007), 'Public research institutions and economic catch-up', Research Policy, 36, 1512-1528

McGahan, A. M. and Silverman, B. S. (2001), 'How does innovative activity change as industries mature?' International Journal of Industrial Organization, 19, 1141-1160 
MCT (2002), Indicadores nacionais de ciencia e tecnologia. Ministerio da ciencia e tecnologia. Mimeo. Minsterio da Ciencia e Tecnologia. Brazil.

MCT (2009) Lei do Bem. http://www.mct.gov.br/index.php/content/view/8586.html, last retrieved in October 2009.

MCT (2009). Indicadores. Ministerio da Ciencia e Tecnologia. http://www.mct.gov.br/index.php/content/view/740.html?execview= , last retrieved November 2009. MCT (2010). Science, Technology and Innovation for Brazil's Development Investing and Innovating to Grow. 2007-2010 Action Plan. Ministerio da Ciencia e Tecnologia. retrieved in February 2011, http://www.brasilemb.org/science-and-technology/policy, Embassy of Brazil, Washington DC

Montobbio, F. and Rampa, F. (2005), 'The Impact of Technology and Structural Change on Export Performance in Nine Developing Countries', World Development, 33, 527-547

Morrison, A. and Rabellotti, R. (2007), 'The role of research in wine: the emergence of a regional research area in an Italian wine production system', International Journal Technology and Globalisation, 3, 155-178.

Mowery, D., Sampat, B. N. (2005), 'The Bayh-Dole Act of 1980 and University-Industry Technology Transfer: A Model for Other OECD Governments?', The Journal of Technology Transfer, 30, 115127.

OECD (2001). Economic surveys: Brazil. OECD.

OECD (2005). University Research Management: Developing research in 12 new institutions. OECD

OECD (2010). Science, Technology and Industry Outlook 2010. OECD.

Pavitt, K. (1984), 'Sectoral patterns of technical change; towards a taxonomy and a theory', Research Policy, 13, 343-373

Pavitt, K. (1998), 'The social shaping of the national science base', Research Policy, 27, 793-805

Powell W., Koput, K. and Smith-Doerr, L. (1996), 'Interorganizational collaboration and the locus of innovation: Networks of learning in biotechnology', Administrative Science Quarterly, 41, 116-145.

Prevenzer, M. (1997), 'The Dynamics of Industrial Clustering in Biotechnology', Small Business Economics, 9(3), 255-71.

Robertson, P. L. and Patel, P. R. (2007), 'New wine in old bottles: Technological diffusion in developed economies', Research Policy, 36, 708-721

Robertson, R L and Smith, K (2008), 'Distributed knowledge bases in low and medium-technology industries'.. In: Hirsch-Kreinsen, H.; Jacobson, D (eds.) Innovation in Low-tech Firms and Industries. p.93-117. Edward Elgar: Cheltenham.

Silva, C. L. and Oliveira, A. (2007), 'Brazilian Industry Policy after 1990: Focusing on the Pharmaceutical Industry'. Journal of Technology Management and Innovation, 2, 71-84.

Silva, E. M. P. (2007), 'A Experiência de Colaboração do Departamento de Engenharia Metalúrgica e de Materiais da UFMG com Empresas - Lições para a Lei de Inovação', Revista Brasileira de Inovação, 6 (2), 433-459 
Storm S. (2008), 'Building Productive Capacities and Technological Capabilities in LDCs'. Development and Change 39(6): 1203-1221.

Development and Change 39(6): 1203-1221 (2008).Strebel, P. (1987), 'Organizing for innovation over an industry cycle', Strategic Management Journal, 8, 117-124

Tushman, M. L. and Anderson, P. (1986), 'Technological discontinuities and Organizational Environments', Administrative Science Quarterly, 31, 439-465

Utterback, J.M. and Abernathy, W. (1975), ‘A dynamic Model of Process and Product Innovation', Omega, 3, 639-656.

Velho, L. and Saenz, T. W. (2002), 'R\&D in the public and private sector in Brazil: complements or substitutes', UNU/ INTECH discussion paper ISN 1564-8370

von Tunzelmann, N. (2009), 'Regional Capabilities and Industrial Regeneration', In Farshchi, M., Janne, O. and McCann, P. (Eds), Technological Change and Mature Industrial Regions: Firms, Knowledge and Policy. p.11-28. Edward Elgar: Cheltenham.

von Tunzelmann, N. and Acha, V. (2005), 'Innovation in 'low-tech' industries', In: Fagerberg, J., Mowery, D.C., Nelson, R.R. (Eds.), The Oxford Handbook of Innovation. p. 407-432. Oxford University Press: Oxford.

Welsh R., L. Glenna, W. Lacy and D. Biscotti, (2008), Close enough but not too far: Assessing the effects of university-industry research relationships and the rise of academic capitalism, Research Policy 37, 1854-1864.

Wong, P-K., Ho, Y.-P and Singh, A. (2007), 'Towards an "Entrepreneurial University" Model to Support Knowledge-Based Economic Development: The Case of the National University of Singapore', World Development, 35, 941-958 
Table 1. Ranking of the motivations of PREO to collaborate with industry

\begin{tabular}{llc}
\hline & \multicolumn{1}{c}{ Motivations } & Average ranking \\
\hline Average order of & Development and transfer of a new technology & $1.33^{\circ}$ \\
importance of & Development of new knowledge & $1.38^{\circ}$ \\
motivations to & Access research funds & $1.75^{\circ}$ \\
collaborate* & Support the innovative capacity of the firm & $2.04^{\circ}$ \\
\hline
\end{tabular}

* Research coordinators were asked to identify by order of importance the main motivation to collaborate with industry. Being 1 the most important motivation and the 4 the least important. 
Table 2. Most common objectives of PREO collaboration with industry

\begin{tabular}{llc}
\hline Common collaboration objectives & $\begin{array}{c}\text { Share of } \\
\text { interviewees that } \\
\text { cite them }\end{array}$ \\
\hline \multirow{2}{*}{ The three most } & development of a new product & 0.8333 \\
common & development of a new process & 0.6250 \\
collaboration & training of firms' employees & 0.5000 \\
objectives & improved process & 0.4167 \\
& improved product & 0.1667 \\
\end{tabular}


Table 3. Factors recognized as Barriers or Facilitators of collaboration with industry

\begin{tabular}{lcc}
\hline & Facilitators & Barriers \\
\hline Location of the university (proximity) & 18 & 2 \\
Public Research sponsoring & 17 & 4 \\
TTOs and similar offices & 15 & 6 \\
Tax incentives & 10 & 5 \\
Administrative support to project management & 10 & 7 \\
Ownership of project's results (patents) & 8 & 11 \\
Long-term projects & 4 & 12 \\
Time required by the firm & 2 & 11 \\
Uncertainty & 0 & 13 \\
Bureaucracy & 0 & 20
\end{tabular}

Note: Total of 24 research coordinators interviewed. The table reports only the number of respondents for which these factors were recognized as barriers or as facilitators. The remaining did not find them to influence the collaboration. 
Table 4. Characteristics of the university-industry collaborative projects analysed

\begin{tabular}{|c|c|c|c|c|c|}
\hline & & ALL & $\begin{array}{c}\text { Emergent } \\
\text { Sector }\end{array}$ & $\begin{array}{l}\text { Spearman's } \\
\text { correlation }\end{array}$ & $\begin{array}{c}\text { Mann-Whitney } \\
\text { T-test } \\
\text { Z } \\
\end{array}$ \\
\hline \multirow{7}{*}{ Objectives } & New product development & 14 & 7 & 0.20 & 0.959 \\
\hline & New process development & 10 & 3 & -0.20 & -0.959 \\
\hline & Services/use of equipment & 3 & 2 & 0.19 & 0.919 \\
\hline & Training of firms' employees & 1 & 1 & $0.25^{\mathrm{a}}$ & $1,183^{a}$ \\
\hline & Improved process & 3 & 0 & $-0.32 *$ & $-1.532 *$ \\
\hline & Improved product & 0 & 0 & . & \\
\hline & Other objectives & 3 & 2 & 0.19 & 0,919 \\
\hline \multirow{6}{*}{ Origin } & Firm contacted university & 8 & 5 & $0.30 *$ & $1.433 *$ \\
\hline & $\begin{array}{l}\text { University contacted the firm/ } \\
\text { propose a project }\end{array}$ & 6 & 1 & $-0.293 *$ & $-1.404 *$ \\
\hline & Co-application to R\&D sponsoring & 6 & 1 & $-0.38 * *$ & $-1.813 * *$ \\
\hline & Students theses and projects & 6 & 4 & 0.19 & 0.919 \\
\hline & Informal contacts & 4 & 1 & -0.18 & -0.845 \\
\hline & Employee training & 1 & 1 & $0.25^{\mathrm{a}}$ & $1.183^{a}$ \\
\hline \multirow{8}{*}{$\begin{array}{l}\text { Financing } \\
\text { Sources }\end{array}$} & $\mathrm{CNPq}$ & 8 & 3 & -0.06 & -0.287 \\
\hline & Fapes & 2 & 1 & 0.05 & 0.244 \\
\hline & Finep & 11 & 4 & -0.10 & -0.475 \\
\hline & Other sources & 18 & 9 & $0.29 *$ & $1.404 *$ \\
\hline & Private & 10 & 5 & 0.14 & 0.685 \\
\hline & Public & 12 & 7 & $0.31 *$ & $1.468^{*}$ \\
\hline & Grants (theses) & 2 & 1 & 0.05 & 0.255 \\
\hline & Average number of sources & 1.79 & 2 & $0.35 * *$ & $1.659 * *$ \\
\hline \multirow{13}{*}{ Outputs } & Theses & 20 & 9 & 0.15 & 0.725 \\
\hline & Publications & 19 & 8 & 0.02 & 0.083 \\
\hline & New product & 13 & 6 & 0.10 & 0.475 \\
\hline & Patent application by the PREO & 12 & 5 & 0.00 & 0 \\
\hline & New process & 9 & 5 & 0.04 & 0.209 \\
\hline & Spin-off & 8 & 4 & 0.12 & 0.573 \\
\hline & Services & 7 & 4 & 0.20 & 0.966 \\
\hline & Licensing & 6 & 2 & -0.10 & -0.468 \\
\hline & Improved process & 4 & 3 & $0.302 *$ & $1.450 *$ \\
\hline & Books & 3 & 3 & $0.447 * *$ & $2.145 * *$ \\
\hline & Average number of outputs & 4.2 & 4.9 & $0.25^{\mathrm{a}}$ & $1.216^{\mathrm{a}}$ \\
\hline & Collaboration after the project & 11 & 2 & $-0.438 * *$ & $-2.101 * *$ \\
\hline & Total number of projects & 24 & 10 & & \\
\hline
\end{tabular}

Note: **Significance at $5 \%$ (one-tailed), $*$ Significance at $10 \%$ (one-tailed), a Significant at $15 \%$ (one-tailed). 
Figure 1. The Offer of supporting services to University-Industry collaboration

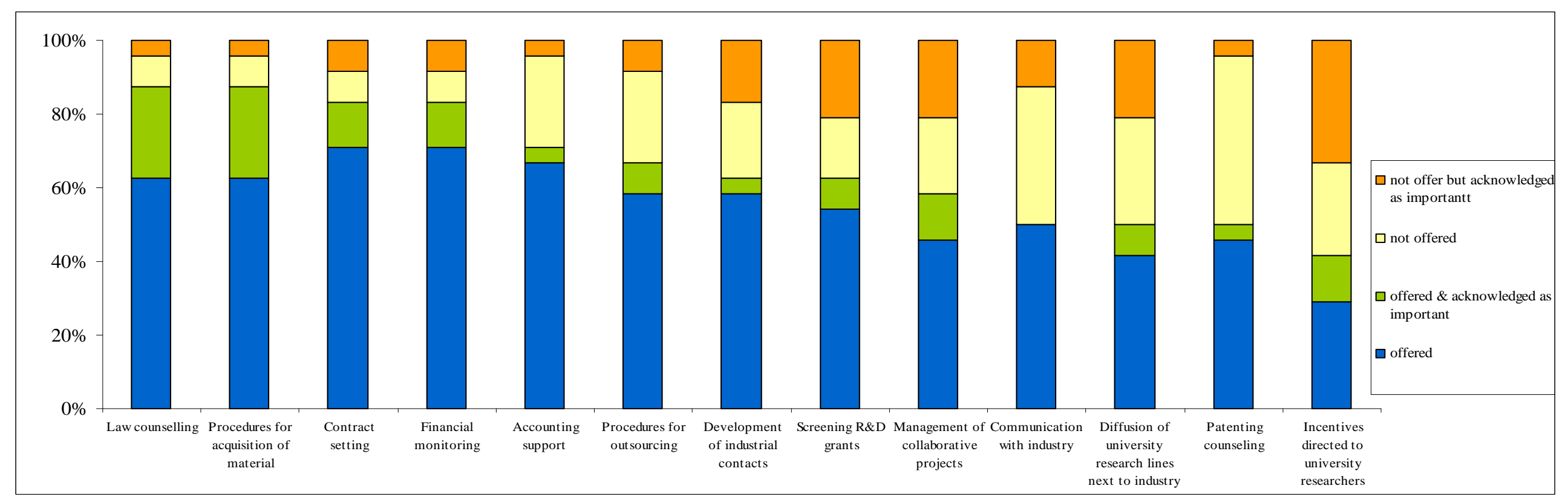

